Article

\title{
Research on Farmers' Willingness of Land Transfer Behavior Based on Food Security
}

\author{
Haizi Wang ${ }^{1}$, Chaowei $\mathrm{Li}^{1}{ }^{1} * \mathbb{C}$, Juan $\mathrm{Liu}^{2}$ and Shibin Zhang ${ }^{1}$ \\ 1 School of Management Engineering, Shandong Jian Zhu University, Jinan 250101, China; \\ wanghz99@sdjzu.edu.cn (H.W.); zhangshibin18@sdjzu.edu.cn (S.Z.) \\ 2 Business School, Shandong Jian Zhu University, Jinan 250101, China; liujuan@sdjzu.edu.cn \\ * Correspondence: 13295415210@163.com
}

Received: 9 February 2019; Accepted: 8 April 2019; Published: 18 April 2019

check for updates

\begin{abstract}
In China, the current household contract responsibility system has been unable to adapt to the commercialization and marketization of rural cultivated land. Rural land transfer is allowed by the government as a supplement to the household contract responsibility system. However, in 2016, the rural land circulating in China accounted for only $35 \%$ of the total national rural land area and there were many problems with the process of land circulation. Therefore, the rural revitalization strategy in China must focus on how to promote rural land circulation with high efficiency to ensure food security in China and high quality to realize the sustainable development of rural land resources. In this study, based on the theory of planned behaviour (TPB), two structural equation models (SEM) for rural land inflow and rural land outflow were used to compare and examine the key factors affecting farmers' intention to engage in rural land circulation in Shandong Province. Data analysed from a survey of 549 farmers showed that behavioural attitudes, subjective norms, and perceptual behavioural control have a significant impact on farmers' intention to engage in rural land circulation, and only subjective norms had a negative impact on the land inflow intention model. Behavioural attitudes had the greatest impact in the two models, but the impact paths of the two models were different. In the rural land inflow intention model, the intrinsic value of cultivated land is important to farmers, whereas in the rural land outflow model, the economic rationality of transferring land was mainly considered. The importance of perceptual behavioural control in the rural land outflow model was greater than it was in the rural land inflow model. The results of this research can provide a reference for formulating government policies, achieving the sustainable development of land resources, and guaranteeing food supply.
\end{abstract}

Keywords: TPB; food security; willingness of rural land transfer; sustainable rural development; SEM

\section{Introduction}

At the beginning of China's economic reform and opening up, the household contract responsibility system played a major role in the stability and development of China's economy. With China's economic development during this era, the factors of agricultural production have undergone tremendous changes, for example, in the efficiency of rural land use, the means of agricultural land use, the scale of agricultural land management and rural labour resource endowment. The scattered and fragmented pattern of land held by single households means that farmers are individuals subject to independent accounting, and thus, the small-scale farmer economy occupies the main position, and large-scale machinery cannot be effectively used, resulting in increased production costs and lower benefits for farmers. Furthermore, with the improvement of rural commercialization and the strengthening of marketization in rural areas, farmers' modernization has been hampered by market information asymmetry, a lack of vertical links between village collectives and villagers or of horizontal links among 
villagers, the adjustment of the agricultural structure [1], and an increasing number of ageing workers on farms [2], all of which have deepened the atomization of farmers. Farmers are trapped in a vicious circle: the atomized individual economy - the selfish tendency of human nature-differentiation and division between farmers-the maintenance of conservative ideas-the further atomization of farmers. Therefore, Chinese agriculture cannot achieve large-scale mechanization, which results in low economic benefits for farmers cultivating crops. A large number of rural young and middle-aged labourers have migrated to cities, creating a labour shortage and reinforcing the ageing workforce in rural areas, and the fragmentation of agricultural land has become a common phenomenon [3-5]. Therefore, farmers lost their motivation to farm or to adopt extensive agricultural management, and some even abandoned their land and left it a wasteland [6]. In 2011 and 2013, 13.5\% and 15\%, respectively, of China's agricultural land was idle [7]. Another problem is land that is not completely abandoned because farmers will return to their village and work on it when they have idle time.

For 14 consecutive years, since 2004, the Party Central Committee and the State Council have included in Central Document No.1 policies to solve the "three rural issues" (agriculture, countryside, and farmers) in China. These range from raising the income of farmers to accelerating the modernization of agriculture, from accelerating urban-rural integration to promoting the supply-side structural reform of agriculture. The introduction of this series of new policies for strengthening agriculture, benefiting farmers and enriching farmers has increased the income of Chinese farmers by an average of $15.86 \%$ per year, but the growth is unstable and non-sustainable. The farmers' income mainly comes from non-agricultural wage income and transfer income; however, agricultural business income and property income, which should be a major component of farmers' income, are unstable, thus threatening the food security of our country. Therefore, in the long run, rural areas play an important role in China's food security, but the inherent motive force and endurance of the stable development of rural areas are insufficient. Central Document No.1 in 2013 clearly stated "Adhere to the principle of voluntary compensation according to law, guide the orderly transfer of rural land contractual management rights, encourage and support the transfer of contracted land to large professional households, family farms, and farmer cooperatives, and develop various approaches of moderate scale management of the farm". Therefore, rural land transfer is a direct entry point to resolving the contradiction between decentralized management and scale effects in the process of agricultural industrialization development [8-10] and, to a certain extent, to expanding the scale of land management, to promoting the restructuring of land, the labour force and other resources, and to ensuring the area planted with grain. In 2014, China first proposed the principle of the "separation of the three powers" for rural land, namely, the principle of ensuring collective ownership, stabilizing farmers' contracting rights, invigorating land management rights, and encouraging land management rights to be properly transferred among farmers, thus ensuring the scale and specialized management of agriculture. This principle has the connotation of bringing a new era and improving the level of rural economic development, promoting sustainable use of land resources [11,12].

However, as in other developing countries, there are still many problems with rural land transfer in China, such as farmers' concurrent operation of rural land, numerous disputes about rural land transfer [13], a lack of projects to drive rural land circulation, imperfect land service systems, and the low efficiency of rural land circulation $[14,15]$, non-grainization and non-agriculturalization of farmland [16]. The root of the problem lies in the fact that the transfer of rural land is, in fact, the transfer of contractual land management rights between two parties, which is a process of transfer from the source of the rural land transfer to the object receiving the land. In addition to the government's common policy measures, the amount of land transferred and the structure of crops planted are mainly determined by farmers' own willingness. Thus, it is undeniable that a deeper understanding of farmers' land transfer behavioural intention is very important.

In order to study the influencing factors of farmers' willingness to transfer land on the premise of ensuring food security, the research in this paper adopted the theory of planned behaviour (TPB) to analyze the factors influencing land transfer intention, namely, behavioural attitude, subjective 
norms and perceived behavioural control, on land transfer behavioural intention, aiming to analyse the factors impacting farmers' inflow and outflow of rural land and the difference between the two models, so as to ensure food security. Specifically, the objectives of this research are as follows:

(i) Compare behavioural attitudes, subjective norms, and perceived behavioural control and their impact on rural land inflow and outflow to obtain a better understanding of the determinants of farmers' land transfer behavioural intentions;

(ii) Make recommendations to help policymakers and organizations promote land transfer in rural areas, reduce the number of rural land abandoned by farmers, so as to achieve the sustainable development of rural land resources and realize the sustainable development of rural economy.

To achieve the above objectives, this research employed an extension of the TPB focused primarily on determinants that affect peasant(farmer) rural land transfer intentions by using structural equation modelling (SEM) as an analysis methodology.

Reaching a deeper understanding of farmers' rural land transfer behavioural intentions increases the likelihood of developing successful public services and policies to increase rural land transfer. Therefore, these research objectives provide not only theoretical contributions but also practical benefits by improving understanding of the relationship between farmers and the land [17]. This study aims to compare farmers' intention to engage in rural land transfer by constructing rural land outflow and inflow models that allow exploration of practical issues to strengthen the understanding of land transfer factors, rural farmers' behavioural intentions and their expected behaviour. Moreover, this work will help researchers and policymakers understand the rural land transfer behavioural intentions of farmers.

\section{Literature Review}

\subsection{Current Status of Land Transfer Research in China}

Rural land transfer in China has been increasing, from 64 million mu in 2007 to 471 million mu in 2016, reaching $35.1 \%$ of the national contracted land area and achieving great results. Scholars at home and abroad have conducted extensive and meticulous research around rural land circulation and have achieved relatively fruitful theoretical results, including the following aspects.

\section{(1) Rural land transfer problem}

Through empirical research in Ethiopia, Bamlaku Alamirew et al. concluded that foreign land transactions increased the possibility of households falling into food insecurity, thus had a negative impact on households' food security [18]. Georgina Rockson et al. believed that land management and food security are consistent, and land transfer, as part of land management, plays an important role in food security [19]. Klaus U. Komp et al. argued that worrying changes in regional food production and growing population require reliable land management tools to be designed and implemented [20]. Joshua Eleonoraetal (2004) [15] analysed the land transfer situation in Czechoslovakia and believed that the interference of government policies did not smooth land privatization, so that it did not reach the ideal state. He found that land transactions were not very common and that land concentration management was not effective, food security was not effectively guaranteed.Through field research in China, Dai and Qin [21] found many problems in the process of land transfer in China, such as imperfect land transfer markets, unsound land management systems, irregular circulation processes, short land circulation periods, unbalanced inter-regional circulation, the backwardness of farmers' thinking, imperfect intermediary service structures, lags in management department services, unclear land property rights systems in rural areas, and conversion of agricultural land to non-growing grain. According to official statistics and satellite imagery, Jie Chen concluded that urbanization has reduced rural population and the number of abandoned farmland has increased rapidly, which will become a great threat to agricultural production in the future [20,22]. Zhang (2011) [23] found a major problem in the existing rural land transfer system in that it lacks relevant legal protection, the rural social security system is imperfect, farmers and local governments are restricted by traditional ideals, relatively 
backward rural infrastructure had affected grain production per unit area. After a land transfer, Wang and $\mathrm{Wu}$ [24] believe that the quality of agricultural land declines [25] and it is difficult to achieve full reclamation during the transfer period, resulting in a decrease in grain production.

(2) Research on the factors affecting rural land transfer

Different peasant(farmer) groups in Jiangxi Province were analysed by Zeng Heng and Chen Mei-qiu et al. [26], who found that farmers in different income groups had different factors affecting circulation. For middle- and high-income peasant(farmer) groups, finding a job away from home was the main reason for land transfer, while for low-income groups, the price of agricultural products was the main factor affecting the land transfer. However, Krusekopf (2002) [27] and Deininger (2008) [28] believed that institutional factors were the most important factors affecting land transfer. Arnab (2002) [29] found that the factors affecting land transfer were the contract system and unfair land resource allocation. After conducting field visits to rural land in China, Brandt (2002) [30] believed that the scale of land transfer in China was inseparable from the relevant government policies. He further noted that the unclear ownership of land hindered the rapid development of China's land transfer market. Through research on 81 villages in Henan Province, Qiao (2011) found that informal relationship networks, land rights, population mobility and the social security system are the main factors affecting farmers' land transfer [31,32]. Based on Qiao Junfeng's study, Shang (2012) noted that the per capita income of households, the cost of agricultural land transfer, the age of decision makers and their years of education affect the land circulation [33]. Wang Jie and Ju Fang found that the total area of the household's contracted land, land fertility, non-agricultural income as a percentage of total income and social endowment insurance had positive effects on rural land transfer [34,35]. Elizabeth Brabec (2002) [36] argued that rural land transfer would result in major changes in the use of land and the scale of land management. At this stage, she found that the greatest obstacle to the development of modern agricultural scale management and the improvement of the land output rate was the fragmentation of land resources. Bogaerts et al. (2002) [37] found that the increase in land transaction costs has largely hindered the conducting of land transactions. Feder Feeney (1993) and Kung J.K. [33] argued that clarity around land property rights can facilitate land transactions. Wang Yahui (2018) et al. [38] found that land quality, geographic location, transaction costs, and household characteristics significantly affected land circulation in different regions by analysing spatial and temporal patterns in land circulation. Terry (2003) [39] believed that many farmers, given their own interests and rational considerations, will have concerns about land transactions that will hinder land circulation and market construction. Thus, a contract may be required for legal protection when transferring land

(3) Research on the rural land transfer mode

Bogaerts [37] noted that land transfer methods were affected by national institutional factors and that unreasonable farmland trade would increase land rents. Due to changes in the land system in China, there are five basic modes of rural land transfer in China: exchanging, subcontracting, renting, stock cooperation, and trust [40]. Liu (2012) [41] proposed a mode of contracting land for social security on the basis of the above. Hao (2015) creatively proposed transfer modes of "farmers + government", "farmers + farmers", "farmers + enterprises + government", and "farmers + economic organizations"; $\mathrm{Li}$ (2016) proposed a mode of rural cooperative organization on the basis of rural land transfer subject differences; Hu [42] proposed a permanently state-owned model. Scholars have also proposed a variety of modes in combination with local regional pilots for land transfer practices. Lin Mei proposed the "enabling the right to confirm the right" mode in Chengdu and the model of "open auctions of land contract management rights" in Qinyang, Henan Province. Jiang Faqin proposed a variety of innovative land models, such as the "Wuhu Model", "Jiaxing Model", "Kunshan Model" and "Guangdong Model". Chen and Zhang extracted the Wenling and Suzhou models of agricultural land stock cooperative systems through empirical investigations in Jiangsu and Zhejiang Provinces. 


\subsection{Theory of Planned Behaviour}

The TPB [43] developed by Ajzen in 1985 is an extension of the theory of reasoned action that adds the perceptual behavioural control factor as a pre-factor influencing individual behavioural intentions, and it is considered to be one of the most effective socio-psychological models for predicting and explaining social behaviours [44-46]. In the TPB, individuals' behaviour is determined by their behavioural intentions, which are influenced by three conceptually independent constructs: behavioural attitudes (personal attitudes), subjective norms (social pressures that influence or enforce behaviour), and perceived behavioural controls (individuals' perceptions of the ease or difficulty of performing specific behaviours) [43,47-49].

Since its launch, the TPB has been used to explore a wide variety of sustainable behaviours and has achieved considerable success. It has been widely applied to sustainable consumption [50], personal positions on sustainable development [51], green buying behaviour [52], and safety and health $[53,54]$. Clearly, the TPB is a useful and powerful framework for supporting studies related to sustainable behaviour, there is sufficient evidence to demonstrate that it is successful in the study of most sustainable behaviours [55,56], and this approach can be applied to most behaviours [57]. Hence, the TPB is now considered to be a preferred theory that can provide a systematic framework for analysing the determinants of factors affecting rural land transfer behavioural intention [58].

This study added past experience of land transfer intentions to the TPB, expanded the theoretical model, and hopes to improve its accuracy. The reason for this extended framework is that past research on rural land transfer can make a considerable contribution to understanding land transfer behaviour. In fact, Ajzen [43] claimed that "The theory of planned behaviour is, in principle, open to the inclusion of additional predictors if it can be shown that they capture a significant proportion of the variance in intention or behavior after the current variables of the theory have been taken into account".

\subsection{Factors Affecting Farmers' Intention to Transfer Rural Land}

Rural land transfer heavily depends on (farmers)peasants engaging in rural land transfer. Hence, it is necessary to understand the farmers' behavioural intention to participate in land transfer to formulate effective policies and strategies to promote land circulation.

Researchers in China and worldwide have conducted many studies of the factors affecting rural land transfer intentions. For instance, Gwendoline (2015) [59] studied the land transaction behaviour of Vietnamese farmers and found that more highly educated farmers with family wealth are more inclined to sell their land. Li Shuangwang (2014) [60] established a binary logistic regression model to analyse the factors influencing the prevalence of rural households' outside of the farming population. The results showed that age, education level, number of migrant workers, family income structure, non-agricultural employment capacity and the distance between the farmland and the city were significantly positively correlated with farmers' land outflow behaviour, but the degree of cultivated land incompleteness was significantly negatively correlated with rural land circulation. From the existing literature, the factors affecting the land transfer of farmers include the gender of the head of the household, education level, physical condition, marital status, farmers' ideology, family population, non-agricultural population ratio [61,62], determination of property rights [63], land location conditions, per capita income, social security [15], difficulty of finding a job, family labour force, non-agricultural income [64], degree of land fragmentation, land transfer income, farmers' expectations for the stability of land rights, agricultural technology application [65], whether there are intermediary organizations in the process of land transfer, changes in the rural production environment [66], whether farmers participate in social security, transaction price of land transfer, cost of land transfer [67], distance between the peasant(farmer) family and town $[1,38]$, government policies $[15,29]$. These studies were based on the basic assumption that farmers, as the subject of behavioural decision-making, face an objective reality that is the basis for their decision-making. However, as social people, only when the objective reality is truly perceived by farmers can it be transformed into a basis for decision-making. 
In addition, farmers' land transfer decisions are affected by many subjective factors, such as the farmer's neighbours, their views on land transfer, their understanding of land transfer or their attitudes.

\section{Theoretical Framework and Hypotheses Development}

As mentioned in the literature review section above, the TPB postulates three pillars that affect behavioural intentions: behavioural attitude, subjective norms and perceived behavioural control. To study the factors affecting farmers' land transfer intentions, this paper takes the extended TPB as the research framework, as shown in Figure 1.

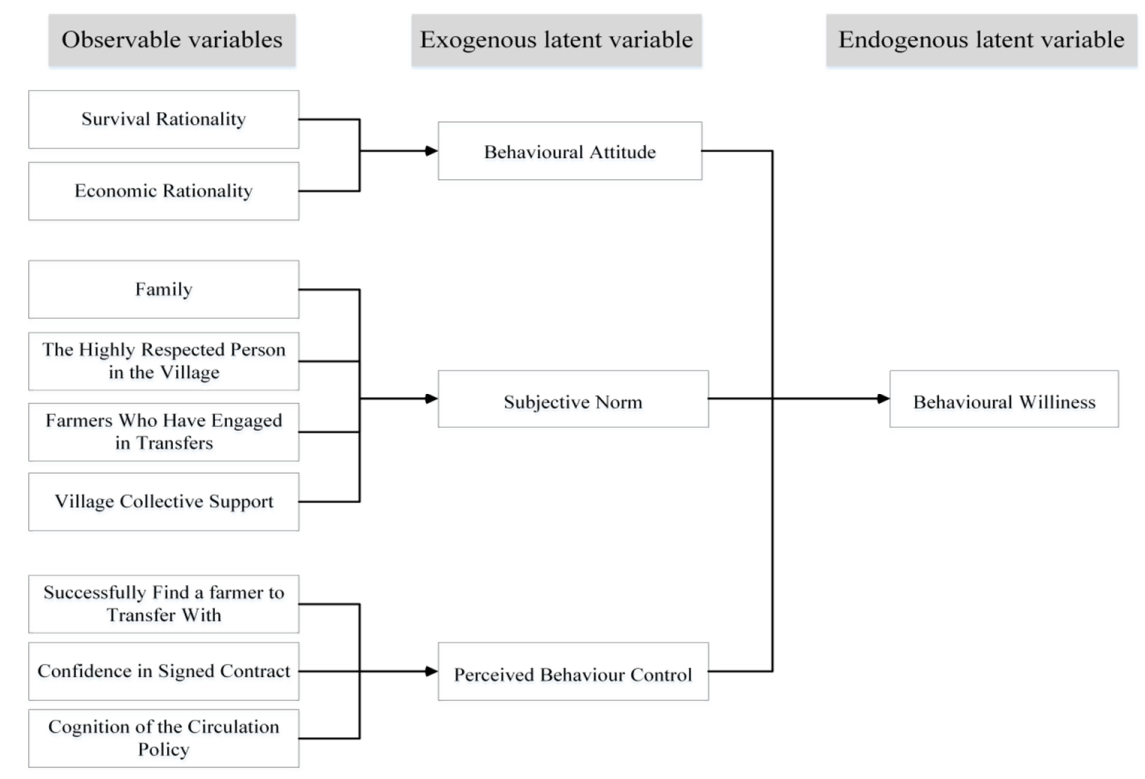

Figure 1. A model of farmers' willingness to engage in rural land transfer based on the theory of planned behaviour.

In the framework, the behavioural attitude was defined as the survival and economic rationales for engaging in rural land transfer. Farmers consider whether a rural land transfer will be beneficial to their own and their families' lives and the economic benefits it will bring. When they believe that potential non-agricultural income will be higher than their agricultural income, rational farmers will transfer their cultivated land to obtain greater economic benefits. The second pillar in the framework is subjective norms, which reflect the social pressure perceived by the individual when performing the behaviour. Farmers' behavioural intentions in their local society is inevitably affected by their families, those who are highly respected in the village, and those who have actually transferred cultivated land. At the same time, the behaviour of the government also has an important impact on farmers' intention to act. The third major factor in the framework is perceived behavioural control, which reflects farmers' perception of the difficulty of engaging in land transfer behaviour. Government policies play a guiding role in peasant(farmer) rural land transfer behaviour, and the degree of development of the circulation market and the ease of access to information also directly affect farmers' perception land transfer behaviour and thus directly affects their intention to transfer land.

Farmers' past experience, gender, education level, income, and residential location are not reflected in the framework used in this paper, but when peasants (farmers) consider a rural land transfer, they inevitably consider their own demographic factors and objective family factors. Therefore, the extended framework used in this study includes these factors and thus has a certain degree of comprehensiveness.

Based on the theoretical model, related studies, and the actual context of rural land transfer in China, this study proposes the following research hypotheses. The research hypothesis model adopted in this study is given in Figure 2. 
Hypothesis 1 (H1). "The more positive farmers' attitude toward land transfer behaviour is, the higher their behavioural intention to engage in rural land inflow".

Hypothesis 2 (H2). "The more positive farmers' attitude toward land transfer behaviour is, the higher their behavioural intention to engage in rural land outflow".

Hypothesis 3 (H3). "Positive subjective norms experienced by farmers are positively related to their behavioural intention to engage in rural land inflow".

Hypothesis 4 (H4). "Positive subjective norms experienced by farmers are positively related to their behavioural intention to engage in rural land outflow".

Hypothesis 5 (H5). "The stronger the farmer's perception of his or her behavioural control is, the stronger his or her behavioural intention to engage in rural land inflow".

Hypothesis 6 (H6). "The stronger the farmer's perception of his or her behavioural control is, the stronger his or her behavioural intention to engage in rural land outflow".

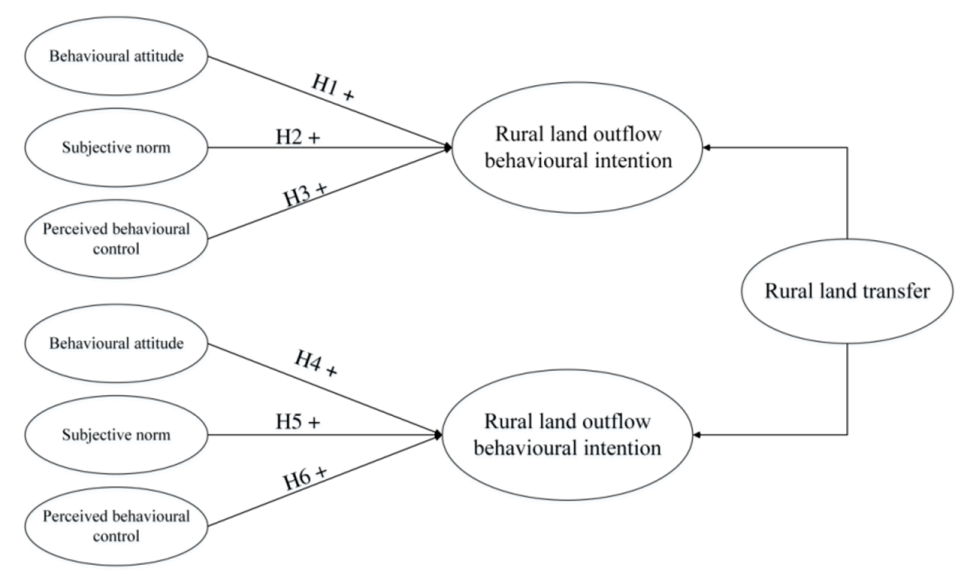

Figure 2. Hypotheses framework.

\section{Research Methodology}

\subsection{Questionnaire Design}

The questionnaire was built based on the literature review and experts' opinions obtained through in-depth interviews combined with author-developed measurement methods; farmers working at home were the research objects. The questionnaire design comprises two parts that aim to meet the research objectives, and the authors strove to obtain accurate results to provide a basis for government policy formulation.

The first section of the questionnaire focuses on the characteristics of the farmer population, including gender, age, education level, total household income, non-agricultural income, actual cultivated land area, and number of laborers. Farmers' intentions to engage in rural land inflow or outflow were explained with the personal information collected in this section.

The second section of the questionnaire captures the intention of farmers to engage in rural land inflow or outflow based on psychological characteristics; these include social pressure, land transfer cognition, transfer costs, past experience, and behavioural will, which are 14 questions in the section, as shown in Table 1. A five-point Likert scale ranging from 1 "strongly negative" to 5 "strongly approve" was used to weigh different dimensions of these questions $[68,69]$. 
Table 1. Reliability and validity test of the scale.

\begin{tabular}{|c|c|c|c|c|c|c|}
\hline & \multirow[b]{2}{*}{ Observable Variable } & \multicolumn{2}{|c|}{ Rural Land Inflow } & \multicolumn{2}{|c|}{ Rural Land Outflow } & \multirow[b]{2}{*}{ References } \\
\hline & & $\begin{array}{l}\text { Standard } \\
\text { Factor } \\
\text { Loading }\end{array}$ & $\begin{array}{l}\text { Cronbach's } \\
\text { Alpha }\end{array}$ & $\begin{array}{l}\text { Standard } \\
\text { Factor } \\
\text { Loading }\end{array}$ & $\begin{array}{l}\text { Cronbach's } \\
\text { Alpha }\end{array}$ & \\
\hline \multirow{5}{*}{$\begin{array}{l}\text { Behavioral } \\
\text { attitude }\end{array}$} & $\begin{array}{l}\mathrm{X} 1 \text { : I think that transferring into or out } \\
\text { of rural land can increase household } \\
\text { income. }\end{array}$ & 0.828 & \multirow{5}{*}{0.802} & 0.867 & \multirow{5}{*}{0.775} & \multirow{5}{*}{$\begin{array}{c}\text { Zhiyang,Yin [70]; } \\
\text { Ajzen [43]; } \\
\text { Feng,Wei [71]; } \\
\text { Mingzhi,Xie [58]; } \\
\text { Deininge [67]; } \\
\text { Terry [39] }\end{array}$} \\
\hline & $\begin{array}{l}\mathrm{X} 2 \text { : The cost of transferring into or out of } \\
\text { rural land is within my acceptable range. }\end{array}$ & 0.725 & & 0.826 & & \\
\hline & $\begin{array}{l}\text { X3: Transferring into or out of rural land } \\
\text { will not affect the amount of land that } \\
\text { will be cultivated in the future. }\end{array}$ & 0.591 & & 0.742 & & \\
\hline & $\begin{array}{l}\text { X4: I think that rural land transfer is } \\
\text { good for both sides. }\end{array}$ & 0.867 & & 0.828 & & \\
\hline & $\begin{array}{l}\text { X5: rural land transfer is valuable to my } \\
\text { family and to the village collective. }\end{array}$ & 0.688 & & 0.769 & & \\
\hline \multirow{4}{*}{$\begin{array}{l}\text { Subjective } \\
\text { norm }\end{array}$} & $\begin{array}{l}\text { X6: My family members support rural } \\
\text { land transfer }\end{array}$ & 0.758 & \multirow{4}{*}{0.775} & 0.812 & \multirow{4}{*}{0.775} & \multirow{4}{*}{$\begin{array}{c}\text { Ajzen; } \\
\text { Yuehui,Wang [72] }\end{array}$} \\
\hline & $\begin{array}{l}\mathrm{X} 7 \text { : Highly respected people in the } \\
\text { village think it is important to transfer } \\
\text { cultivated land }\end{array}$ & 0.75 & & 0.745 & & \\
\hline & $\begin{array}{l}\text { X8: People who have transferred } \\
\text { cultivated land in the village believe that } \\
\text { transferring rural land is beneficial. }\end{array}$ & 0.585 & & 0.546 & & \\
\hline & $\begin{array}{l}\text { X9: Village collectives support rural land } \\
\text { transfer }\end{array}$ & 0.511 & & 0.447 & & \\
\hline \multirow{3}{*}{$\begin{array}{l}\text { Perceptual } \\
\text { behavior } \\
\text { control }\end{array}$} & $\begin{array}{l}\text { X10: If I want to transfer the rural land, I } \\
\text { can successfully find a party for the } \\
\text { transfer. }\end{array}$ & 0.774 & \multirow{3}{*}{0.759} & 0.7 & \multirow{3}{*}{0.776} & \multirow{3}{*}{$\begin{array}{c}\text { Merav Ben } \\
\text { Natan [73]; } \\
\text { Feng,Wei [71] }\end{array}$} \\
\hline & $\begin{array}{l}\mathrm{X} 11 \text { : If there is a perfect contract, I am } \\
\text { likely to transfer the land. }\end{array}$ & 0.819 & & 0.899 & & \\
\hline & $\begin{array}{l}\text { X12: Some people in our family are } \\
\text { familiar with the policy of rural land } \\
\text { transfer and understand the land } \\
\text { transfer procedure. }\end{array}$ & 0.797 & & 0.783 & & \\
\hline \multirow{2}{*}{$\begin{array}{l}\text { Behavioral } \\
\text { intention }\end{array}$} & $\begin{array}{l}\text { Y1: I think that I would be willing to } \\
\text { transfer rural land. }\end{array}$ & 0.431 & \multirow{2}{*}{0.75} & 0.381 & \multirow{2}{*}{0.748} & \multirow{2}{*}{$\begin{array}{c}\text { Fishbein; } \\
\text { Feng,Wei [74] }\end{array}$} \\
\hline & $\begin{array}{l}\text { Y2: If there is a chance, I will transfer the } \\
\text { rural land. }\end{array}$ & 0.589 & & 0.507 & & \\
\hline
\end{tabular}

\subsection{Questionnaire Pre-Test}

To test the quality of the questionnaire design, a corrective test of the questionnaire was needed to ensure its reliability and accuracy. In this study, 60 farmers were selected for pilot research. Each invited participant completed the questionnaire in the presence of the questioner, who collected the questionnaire and analysed the data to modify and improve it. The reliability and validity of the questionnaires tested in the pilot test are shown in Table 1.

A reliability test refers to the consistency of the results obtained when the same subject is repeatedly measured in the same way. A reliability test commonly uses Cronbach's alpha $(\alpha)$, which was used here to determine the reliability and validity of the questionnaire. Table 2 shows that the Cronbach's alpha $(\alpha)$ values for the rural land inflow model and the rural land outflow model ranged from 0.75 to 0.802 and 0.748 to 0.776 , respectively, and the Cronbach's alpha $(\alpha)$ values for the rural land inflow and outflow model of the questionnaire were 0.932 and 0.927 , respectively. All of the items in the questionnaire passed the threshold for Cronbach's alpha $(\alpha)$, which was set at greater than 0.7 , placing them within the accepted range. Therefore, the questionnaire used in this study was very reliable. A validity test refers to the degree to which the measured result reflects the content to be examined. The more consistent the measurement result is with the content to be examined, the higher the validity. The validity test includes a test of content and structural validity. The scale of this paper was based on a screening method of scale items used by previous studies, and the items of the scale were determined 
by combining a large number of earlier studies. Therefore, the content validity of the scale is reasonable. An SPSS21.0 calculation determined that the standard factor loading of each observed variable for transferring to cultivated land and transferring out of cultivated land was above 0.5 (Table 2), and only the loading for individual willingness was less than 0.5 , indicating that the structural validity of each potential variable was valid.

Table 2. Feature description of the survey sample.

\begin{tabular}{cccc}
\hline & Sample Content & Quantity & Proportion \\
\hline \multirow{2}{*}{ Gender } & Male & 372 & 67.8 \\
& Female & 177 & 32.2 \\
\hline \multirow{4}{*}{ Age } & Under 30 years old & 64 & 11.71 \\
& $30-40$ & 79 & 14.42 \\
& $40-50$ & 151 & 27.51 \\
& $50-60$ & 200 & 36.43 \\
Education Level & Over 60 years old & 51 & 9.22 \\
\hline \multirow{5}{*}{ Family population } & Elementary school and below & 107 & 19.45 \\
& Junior high school & 238 & 43.27 \\
& High school & 156 & 28.39 \\
& Over high school & 49 & 8.89 \\
\hline & One or two people & 69 & 12.56 \\
& Three people & 149 & 27.13 \\
& Four people & 194 & 35.35 \\
& Five people & 81 & 14.73 \\
& Six or more people & 56 & 10.23 \\
\hline
\end{tabular}

\subsection{Research Foundation}

As a major agricultural province in China, Shandong Province had a total grain output of 47.23 million tons in 2017, accounting for 7.64\% of the national grain, ranking third in China's provinces for output, and playing an important role in the stability of China's grain output. Therefore, analysis of the intention to transfer contractual management rights is a great significance. Given the differences in the development status across the region, the level of agricultural development also varies, and there are certain differences in the factors affecting the farmers' intention to rural land transfer. This survey selected Yucheng County, Lianshui County, Qingzhou City (county-level city), Jiaxing County, Longkou City (county-level city) and Laizhou City (county-level city), which represents 6 counties and cities with 30 natural villages. The survey data were collected from questionnaires administered in rural areas of Shandong Province from January to March 2018 through one-on-one interviews with farmers. From each county and city, 30 villages were selected and then 20 families were randomly selected in each village, based on the location of families in the village, population, living environment and so on. Each family chose an adult farmer for interviews who were determined based on family economic status, age, gender, etc., so as to ensure representativeness of the total sample. Considering the difference in the economic situation of the rural households in the village, the number of samples will increase, but in the end, each village still chooses 20 samples. A total of 600 questionnaires were sent out in this survey, excluding invalid questionnaires with incomplete answers, of which 549 were returned and valid, with an effective rate of $91.5 \%$. Among them, 192 households were circulating land, accounting for 34.97 percent, including 108 households were only transferred into land, 74 households were only transferred out rural land, while 10 households have transferred both out of and into rural land. The sample characteristics of the survey are described in Table 2. It can be seen from the data in table 2 that the average age of farmers is 46.7 years old, the average family population is 3.8 , the education level is low, the average family disposable income is about 13 thousands yuan, which is close to the national average income of 15,117 yuan in rural areas of Shandong Province in 2017. Therefore, the overall sample is in line with the current situation of farmers in Shandong Province, and has a relatively high representation of the whole Shandong Province. 


\subsection{Data Analysis}

Confirmatory factor analysis was used to test whether the relationship between a factor and the corresponding measure is in accordance with the theoretical relationship designed by the researcher. The process of confirmatory factor analysis is also the process for testing the measurement model. J. C. Anderson and D. W. Gerbin suggest that in the process of developing theory, the model should first be established through exploratory factor analysis, and the results of the model then provide an important basis and guarantee for the establishment of hypotheses to be tested with confirmatory factor analysis. Exploratory factor analysis is required first.

In this paper, SPSS21.0 software was used to conduct exploratory factor analysis on the data. The KMO (Kaiser-Meyer-Olkin) values for the rural land inflow model and rural land outflow model were 0.93 and 0.909 , respectively; the Bartlett's sphericity test values were 554.335 and 535.765 , respectively; and $p$ value is less than $0.01(p=0.000)$. Therefore, this study is suitable for confirmatory factor analysis.

This paper used AMOS24.0 software to perform confirmatory factor analysis on the obtained data. The results of the analysis are shown in Tables 3 and 4. It can be seen from the results that in the model for cultivated land inflow, the standardized path coefficients from behavioural attitude, subjective norms and perceptual behavioural control to the intention to engage in cultivated land inflow are 0.827 , -0.153 and 0.403 , respectively, at $10 \%, 10 \%$ and $5 \%$ significance levels, respectively. In the rural land outflow model, the standardized path coefficient from behavioural attitude to the willingness to engage in cultivated land outflow was 0.466 , and through the $1 \%$ significance test, the standardized path coefficient from subjective norms to rural land outflow was 0.294 at a $10 \%$ significance level. Notably, the standardization coefficient from perceptual behavioural control to the willingness to engage in cultivated land outflow was 0.338 at a $5 \%$ significance level. In addition, all potential variables and observable variables in the two models are significant with a $99 \%$ confidence interval, and the $t$-values of the load coefficients are greater than 2, indicating that the models are significantly significant. Then, the model fit test was carried out on the two rural land transfer models, and the results are shown in Table 4. All the fit index values of the models are within the accepted standard range. Therefore, the overall fit of the model is better.

Table 3. Rural land inflow models' path and load factor estimation results.

\begin{tabular}{|c|c|c|c|}
\hline \multirow[b]{2}{*}{ Path/Load Factor } & \multicolumn{3}{|c|}{ Rural Land Inflow } \\
\hline & $\begin{array}{l}\text { Non-Standardized } \\
\text { Path/Load Factor }\end{array}$ & C.R Value & $\begin{array}{c}\text { Standardized } \\
\text { Path/Load Factor }\end{array}$ \\
\hline Behavioural will $\leftarrow$ Behavioural attitude & 0.95 & $1.787^{*}$ & 0.827 \\
\hline Behavioral will $\leftarrow$ Subjective norm & -0.196 & $-0.352 *$ & -0.153 \\
\hline Behavioural will $\leftarrow$ Perceptual behaviour control & 0.473 & $0.9 * *$ & 0.403 \\
\hline $\mathrm{X} 1 \leftarrow$ Behavioural attitude & 1 & & 0.737 \\
\hline $\mathrm{X} 2 \leftarrow$ Behavioural attitude & 0.805 & $6.301 * * *$ & 0.626 \\
\hline $\mathrm{X} 3 \leftarrow$ Behavioral attitude & 0.794 & $6.129 * * *$ & 0.61 \\
\hline $\mathrm{X} 4 \leftarrow$ Behavioural attitude & 1.026 & $7.655^{* * *}$ & 0.75 \\
\hline $\mathrm{X} 5 \leftarrow$ Behavioural attitude & 0.784 & $6.274 * * *$ & 0.624 \\
\hline $\mathrm{X} 6 \leftarrow$ Subjective norms & 1.084 & $6.813^{* * *}$ & 0.736 \\
\hline $\mathrm{X} 7 \leftarrow$ Subjective norms & 0.996 & $6.205^{* * *}$ & 0.662 \\
\hline $\mathrm{X} 8 \leftarrow$ Subjective norms & 0.938 & $6.157^{* * *}$ & 0.656 \\
\hline $\mathrm{X} 9 \leftarrow$ Subjective norms & 1 & & 0.661 \\
\hline $\mathrm{X} 10 \leftarrow$ Perceptual behaviour control & 0.904 & $6.597^{* * *}$ & 0.688 \\
\hline $\mathrm{X} 11 \leftarrow$ Perceptual behaviour control & 1.004 & $7.176^{* * *}$ & 0.748 \\
\hline $\mathrm{X} 12 \leftarrow$ Perceptual behaviour control & 1 & & 0.715 \\
\hline 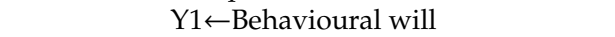 & 0.87 & $8.87^{* * *}$ & 0.75 \\
\hline Y2 Behavioural will & 1 & & 0.8 \\
\hline
\end{tabular}

Note: ${ }^{* * *},{ }^{* *}$ and ${ }^{*}$ indicate significant at the $1 \%$ level, $5 \%$ and $10 \%$ levels respectively; C.R value is the $t$ value. 
Table 4. Rural land outflow models' path and load factor estimation results.

\begin{tabular}{|c|c|c|c|}
\hline \multirow[b]{2}{*}{ Path/Load Factor } & \multicolumn{3}{|c|}{ Rural Land Outflow } \\
\hline & $\begin{array}{l}\text { Non-Standardized } \\
\text { Path/Load Factor }\end{array}$ & C.R Value & $\begin{array}{c}\text { Standardized } \\
\text { Path/Load Factor }\end{array}$ \\
\hline Behavioural will $\leftarrow$ Behavioural attitude & 0.558 & $2.81^{* * *}$ & 0.466 \\
\hline Behavioral will $\leftarrow$ Subjective norm & 0.377 & $1.737^{*}$ & 0.294 \\
\hline Behavioural will $\leftarrow$ Perceptual behaviour control & 0.375 & $2.398^{* *}$ & 0.336 \\
\hline $\mathrm{X} 1 \leftarrow$ Behavioural attitude & 1 & & 0.707 \\
\hline $\mathrm{X} 2 \leftarrow$ Behavioural attitude & 0.854 & $6.322 * * *$ & 0.636 \\
\hline $\mathrm{X} 3 \leftarrow$ Behavioral attitude & 0.785 & $5.628 * * *$ & 0.566 \\
\hline $\mathrm{X} 4 \leftarrow$ Behavioural attitude & 0.943 & $6.735 * * *$ & 0.677 \\
\hline X5 Behavioural attitude & 0.796 & $5.898^{* * *}$ & 0.593 \\
\hline $\mathrm{X} 6 \leftarrow$ Subjective norms & 1.107 & $6.949 * * *$ & 0.745 \\
\hline $\mathrm{X} 7 \leftarrow$ Subjective norms & 1.002 & $6.26^{* * *}$ & 0.66 \\
\hline $\mathrm{X} 8 \leftarrow$ Subjective norms & 0.943 & $6.207^{* * *}$ & 0.653 \\
\hline X9セSubjective norms & 1 & & 0.655 \\
\hline $\mathrm{X} 10 \leftarrow$ Perceptual behaviour control & 0.846 & $6.161 * * *$ & 0.646 \\
\hline $\mathrm{X} 11 \leftarrow$ Perceptual behaviour control & 1.09 & $7.958^{* * *}$ & 0.839 \\
\hline $\mathrm{X} 12 \leftarrow$ Perceptual behaviour control & 1 & & 0.749 \\
\hline Y1 $\leftarrow$ Behavioural will & 0.888 & $8.835^{* * *}$ & 0.758 \\
\hline Y2 Behavioural will & 1 & & 0.791 \\
\hline
\end{tabular}

Note: ${ }^{* * *},{ }^{* *}$ and ${ }^{*}$ indicate significant at the $1 \%$ level, $5 \%$ and $10 \%$ levels respectively; C.R value is the $t$ value.

\section{Results and Discussion}

Based on the TPB, it can be seen from the data estimation results (Tables 3 and 4) that rural land inflow and outflow intentions were significantly affected by the three variables behavioural attitudes, subjective norms and perceived behavioural control. The model fitting test indicators are shown in Table A1 in the Appendix A.

The path coefficient from behavioural attitude to the farmer's rural land transfer intention in the rural land inflow model is 0.827 , and it was significant at the $10 \%$ level. The path coefficient in the rural land outflow model was only 0.466 , which is highly significant at the $1 \%$ level, indicating that there is a significant difference in the influence of behavioural attitudes between the rural land inflow and outflow models. The effect of behavioural attitude on the intention of rural land inflow is greater than rural land outflow. It can be seen in Tables 3 and 4 that among the five observable variables of behavioural attitude, the greatest impact on cultivated land inflow was from "I think that rural land transfer is good for both sides (X4)", which has a standardized path load factor of 0.75 . The greatest impact on cultivated land outflow was from "I think that transferring into or out of rural land can increase household income (X1)", and the standardized load factor was 0.707 . This conclusion has been confirmed by ZENG Heng et al. that the level of agricultural income is the most important factor affecting farmers' rural land transfer behavior [26]. The above analysis shows that the main consideration for farmers when considering cultivated land outflow was the increase in income, but the first consideration when transferring into cultivated land was protecting the benefits of those who have transferred out of rural land, indicating that cultivated land inflow is more concerned with economic income, while outflow mainly considers the inherent value of the cultivated land. In addition, in the survey, it was found that $63 \%$ of the farmers who are willing to engage in cultivated land outflow cannot identify a transferee and so cannot transfer. Meanwhile, $72 \%$ of farmers who have the intention to cultivate land inflow lack sufficient funds and good farming projects.

The path coefficient in the rural land inflow model from subjective norms to the willingness to engage in rural land transfer was -0.153 , which is significant at the level of $10 \%$. The negative value mainly stems from poor information regarding land circulation, and farmers actually contact or understand that the phenomenon of losing money due to rural land inflow, which caused the farmers to feel fearful. The path coefficient for the willingness to engage in rural land outflow model was 0.294, which was significant at the $10 \%$ level. Thus, the effect of subjective norms on the intention of rural land inflow is greater than rural land outflow. As seen from Tables 3 and 4 , among the four observable 
variables within subjective norms, the most influential factors in the rural land inflow and outflow models are "my family members support rural land transfer (X6)", with standardized path coefficients of 0.736 and 0.745 , respectively. The gap between the two models is not obvious. It can be seen that the influence of other people over farmers regarding land inflow or outflow to was consistent, but in the process of analysis, it was found that the influence factors of family members on the willingness to transfer cultivated land were 0.736 for inflow and 0.662 for outflow, which were larger than those for other transferees and village collectives $(0.656,0.661$ and $0.653,0.655)$. Similarly, the influence factors of highly respected people in the village on the willingness to engage in cultivated land inflow and outflow were 0.745 and 0.66 , respectively, which were also larger than the standardized load factors for other transferred farmers and village collectives. These results show that the influence of family is crucial when farmers make decisions regarding rural land transfer. In addition, the highly respected people in the village have an important influence on intention of rural land transfer, so the village head plays an important role in the village's economic development. By comparing the models of rural land inflow and outflow, it can be seen that the influence of family on the rural land outflow model is greater than that on the rural land inflow model and that highly respected people in the village also have an important influence. This is consistent with the research of Yin Zhiyang, etc. They also believe that farmers have a herd mentality in the process of rural land transfer, but it is not the main reason that affects rural land transfer [70].

The path coefficient of perceptual behavioural control in the rural land inflow model was 0.403 , which was significant at the $5 \%$ level; in the rural land outflow model, the path coefficient of intention to engage in rural land transfer was 0.336 , which is also significant at the $5 \%$ level. The effect of perceptual behavioural control on the intention of rural land inflow is greater than rural land outflow. It can be seen from Tables 3 and 4 that among the three observed variables for perceived behavioural control, the most influential factor for the models of land inflow and rural land outflow was "if there is a perfect contract, I am likely to transfer land (X11)", with a standardized load factor of 0.748 and 0.839 , respectively. It shows that in the process of rural land transfer, regulating the rural land transfer behavior of both sides of rural land transfer plays an important role in promoting land transfer. Therefore, improving the rural land transfer market is an important way to promote land transfer [9]. However, the standardization coefficient of the rural land outflow model was larger than that of the rural land inflow model, indicating that the rationality of the procedure was more important to farmers' when considering cultivated land outflow than when considering cultivated land inflow. We also found that the other two observable variables "... I can successfully find a transfer party" and " ... familiar with the policy for rural land transfer ... " were significant at the $1 \%$ level for farmers' perceptual behavioural control, showing that farmers' understanding of land policy and the difficulty of obtaining information can truly influence their willingness to transfer and can safeguard their legitimate rights and interests, and information will play an increasingly important role in the future land transfer process. Therefore, the rural land transfer information of farmers can only be transmitted through a certain medium and received by the other party in need. Further, Xie Mingzhi etc. believe that the construction of a platform for land transfer information plays an equally important role in the occurrence of land transfer behavior [58].

\section{Conclusions}

Based on the TPB, this paper added past experience of land transfer intentions to expand the theoretical model, improved its accuracy. Therefore, this study tested the main factors that affect farmers' intention to transfer land considering the two aspects of rural land outflow and inflow and determined the difference between the factors driving outflow and inflow, and provided a reference and information source for future research, and provided a reference to realize the Sustainable Development of Rural Economy. First, behavioural attitudes have different effects on rural land inflow versus outflow. Farmers transferring into cultivated land mainly considered the inherent value of the cultivated land and considered the benefits being received by the transferee. The farmers who transferred out of 
cultivated land mainly consider economic rationality and the increase to household income. Second, the four observable variables under subjective norms had a consistent effect on the transfer into and out of rural land. When farmers were engaged in rural land transfer, they first referred to the opinions of the family members, and the suggestions of the highly respected people in the village also had an important influence. Hence, there is a herd mentality in rural land transfer. Third, the contractual consciousness of farmers within perceptual behaviour control is more important to rural land outflow than to rural land inflow. In addition, farmers' mastery of the transfer policy and circulation information also has a strong impact on their intention to engage in rural land transfer. Farmers who are very familiar with land policy and obtain transfer information may become the dominant players in the transfer of cultivated land.

Based on the conclusions from the above analysis, to improve farmers' willingness to transfer rural land, to guarantee the efficient use of rural land resources and ensure food security effectively, the following policy recommendations are offered. First, adjusting the policy orientation in the transfer of land contracting and management right. The policy tendency of local government in the transfer of land contracting and management rights has a relatively important impact on food security. It is necessary to solve the scissors gap between the benefits of grain production and other economic crops or high-efficiency agricultural benefits through the means of government support, according to various regions in China. The endowment of environmental resources and cultivated land resources, the transfer of rural land with the principle of "suitable for grain production to ensure food production and development of efficient agriculture for efficient agriculture". Second, improving the policy of grain subsidy and increasing farmers' enthusiasm for growing grain. In order to improve the enthusiasm of the actual grain growers, the state should grant grain subsidies to the operators directly engaged in grain cultivation, regardless of whether they have the right to contract the land or not. In addition, it can treat food crop production and other economic crop production, large grain production households and small grain production households differently, give food production subsidies higher than economic crop production, and give large grain farmers more in the main grain production and management More subsidies will mobilize the enthusiasm of farmers to grow grain and stimulate the production of food, thus ensuring food security.

There are some limitations of the research in this study. Firstly, this paper only analyzed the factors affecting land transfer according to the theory of planned behavior. The factors selected are not comprehensive enough, for example, the use of agricultural technology and the difference in the number of labor population in the village are not considered in the model. Secondly, due to the large geographical area of China, the development of rural areas in each province is different. Except for Shandong Province in China, the results of this study may not be suitable in other provinces, especially in the western provinces of China. Therefore, many future studies can extend this research, providing a research basis for rural revitalization in China and sustainable economic development in rural areas.

Author Contributions: Conceptualization, H.W., C.L.; methodology, C.L.; software, C.L., J.L., S.Z.; formal analysis, C.L.; writing-review and editing, H.W., C.L., J.L., S.Z.; supervision, C.L.; funding acquisition, H.W.

Funding: This research received no external funding .

Conflicts of Interest: The authors declare no conflict of interest.

\section{Appendix A}

Table A1. Model fit test indicator.

\begin{tabular}{ccccccccc}
\hline Statistical Test & $\chi^{\mathbf{2}} / \mathbf{d f}$ & GFI & AGFI & NFI & CFI & RMSEA & RMR & TLI \\
\hline Evaluation standard & $<3$ & $>0.9$ & $>0.8$ & $>0.9$ & $>0.9$ & $<0.05$ & $<0.05$ & $>0.9$ \\
Model 1: Transfer & 1.714 & 0.901 & 0.847 & 0.904 & 0.995 & 0.022 & 0.047 & 0.994 \\
Model 2: Roll out & 1.018 & 0.902 & 0.855 & 0.910 & 0.998 & 0.014 & 0.04 & 0.998 \\
\hline
\end{tabular}




\section{References}

1. Lei, Z.B. Driving Factors and Model of Change in Arable Land Area in China. Asian Agric. Res. 2009, 1, 35-38.

2. Feng, Z.D.; Huo, L.; Shao, C.L. A review on rural land circulation of China. J. Northwest Univ. 2010, 2, $23-29$.

3. Liu, Y.; Yang, R.; Long, H.; Gao, J.; Wang, J. Implications of land-use change in rural China: A case study of Yucheng, Shandong province. Land Use Policy 2014, 40, 111-118. [CrossRef]

4. Zhang, Y.; Xiubin, L.I.; Song, W. Determinants of cropland abandonment at the parcel, household and village levels in mountain areas of China: A multi-level analysis. Land Use Policy 2014, 41, 186-192. [CrossRef]

5. Gu, S.; Wang, X.; Lu, J.; Wang, Y.; Zhang, X. Land moving mode in rural areas, its domino effect and innovation. Chin. J. Agric. Resour. Reg. Plan. 2009, 30, 1-8.

6. Deininger, K.; Savastano, S.; Carletto, C. Land fragmentation, cropland abandonment, and land market operation in Albania. World Dev. 2012, 40, 2108-2122. [CrossRef]

7. Gan, L.; Yin, Z.; Tan, J. China Household Finance Survey Report 2014; Southwestern University of Finance and Economics Press: Chengdu, China, 2015.

8. Du, Y.; Bo, S. The development of chinese agricultural land transfer system: Transaction, concentration and commercialization. J. Agric. Sci. 2011, 3, 269-274.

9. Wu, H.; Miao, Y.H.; Jiang, H.; Xu, D.; Jiao, W.P. Improving the circulation market of land contractual management rights for land operation with proper scale-up. Chin. Agric. Sci. Bull. 2008, 12, 123.

10. Yan, M. Research on rural tourism development based on the new policy of land circulation. Asian Agric. Res. 2009, 1, 19-22.

11. Zhou, L. Chinese comprehensive rural reform: Institutional vicissitude, theoretic framework and content structure. J. Northeast Agric. Univ. 2015, 22, 79-90.

12. Zhang, X.; Shan, Z. The research review of land-use and land-management problems in the joint of urban and Rural area for the last two decades. Energy Procedia 2012, 16, 353-358.

13. Cao, W.K.; Wu, D.E. Contract system for circulation of the right to rural land contractual management. Asian Agric. Res. 2010, 2, 53-57.

14. Jin, S.; Deininger, K. Land rental markets in the process of rural structural transformation: Productivity and equity impacts from China. J. Compar. Econ. 2009, 37, 629-646. [CrossRef]

15. Duke, J.M.; MarišOvá, E.; Bandlerová, A.; Slovinska, J. Price repression in the Slovak agricultural land market. Land Use Policy 2004, 21, 59-69. [CrossRef]

16. Chen, J. Rapid urbanization in China: A real challenge to soil protection and food security. CATENA 2007, 69, 1-15. [CrossRef]

17. Lin, Y.P. Different Characteristics of Peasant Issues from the Connections between Peasants and Land. Asian Agric. Res. 2010, 2, 36-39.

18. Alamirew, B. Do land transfers to international investors contribute to employment generation and local food security?: Evidence from Oromia Region, Ethiopia. Proc. SPIE Int. Soc. Opt. Eng. 1996, 78, 438-444. [CrossRef]

19. Rockson, G.; Bennett, R.; Groenendijk, L. Land administration for food security: A research synthesis. Land Use Policy 2013, 32, 337-342. [CrossRef]

20. Komp, K.U.; Haub, C. Global monitoring for food security and sustainable land management -recent advances of remote sensing applications to african and siberian show cases. ISPRS Int. Arch. Photogramm. Remote Sens. Spat. Inf. Sci. 2012, XXXIX-B8, 265-270. [CrossRef]

21. Qin, S.M.; Chen, Y.H.; Li, M.; Cai, Z.H.; Liu, Z.W. Land circulation in Guangxi rural areas and countermeasure analysis: Based on investigations of 7 towns and 13 villages in Nanning and Guilin. Sci. Technol. Manag. Land Resour. 2013, 30, 110-114. (In Chinese)

22. Delville, P.L. Competing conceptions of customary land rights registration (rural land maps PFRs in Benin): Methodological, policy and polity issues. Soc. Anthropol. Ethnol. 2014, 5, 1-24.

23. Zhang, C.C. The Major Problems and the Governmental Role in Chinese Rural Land Transfer. Asian Agric. Res. 2011, 3, 62-65.

24. Wang, S.H. Analysis of hidden danger in farmer's rights and interests during Farmland Transfer-An evaluation of rights safeguarding effect of farmland transfer contract. Asian Agric. Res. 2010, 2, 61-64. 
25. Wang, J.; Chen, Y.; Shao, X.; Zhang, Y.; Cao, Y. Land-use changes and policy dimension driving forces in China: Present, trend and future. Land Use Policy 2012, 29, 737-749. [CrossRef]

26. Zeng, H.; Chen, M.Q.; Zhou, B.J. Empirical Study on the Will of Farmland Transfer among Different Farmer Groups-A Sampling Survey on 42 Counties and Cities, 64 Towns and 74 Villages in Jiangxi Province. Asian Agric. Res. 2011, 3, 58-62.

27. Krusekopf, C.C. Diversity in land-tenure arrangements under the household responsibility system in China. China Econ. Rev. 2002, 13, 297-312. [CrossRef]

28. Deininger, K.; Jin, S.; Nagarajan, H.K. Efficiency and equity impacts of rural land rental restrictions: Evidence from India. Eur. Econ. Rev. 2008, 52, 892-918. [CrossRef]

29. Basu, A.K. Oligopsonistic Landlords, Segmented Labor Markets, and the Persistence of Tied-Labor Contracts. Am. J. Agric. Econ. 2002, 84, 438-453. [CrossRef]

30. Brandt, L.; Huang, J.; Li, G.; Rozelle, S. Land rights in rural china: facts, fictions and issues. China J. 2002, 47, 67-97. [CrossRef]

31. Feng, S.; Heerink, N. Are farm households' land renting and migration decisions inter-related in rural China? NJAS Wagening. J. Life Sci. 2008, 55, 345-362. [CrossRef]

32. Smyth, R.; Nielsen, I.; Zhai, Q. Subjective well-being of China's off-farm migrants. J. Happiness Stud. 2010, 11, 315-333.

33. Pender, J.L.; Kerr, J.M. The effects of land sales restrictions: Evidence from south India. Agric. Econ. 1999, 21, 279-294. [CrossRef]

34. Che, Y. Mismatch: Land reallocations, recovery land rental and land rental market development in rural China. MPRA Pap. 2009, 6, 229-247. [CrossRef]

35. Kung, K.S. Off-Farm Labor Markets and the Emergence of Land Rental Markets in Rural China. J. Comp. Econ. 2002, 30, 395-414. [CrossRef]

36. Brabec, E.; Smith, C. Agricultural land fragmentation: The spatial effects of three land protection strategies in the eastern United States. Landsc. Urban Plan. 2002, 58, 255-268. [CrossRef]

37. Bogaerts, T.; Williamson, I.P.; Fendel, E.M. The role of land administration in the accession of Central European countries to the European Union. Land Use Policy 2002, 19, 29-46. [CrossRef]

38. Wang, Y.H.; Li, X.B.; Xin, L.J.; Tan, M.H.; Jiang, M. Spatiotemporal changes in Chinese land circulation between 2003 and 2013. J. Geogr. Sci. 2018, 28, 707-724. [CrossRef]

39. Dijk, T.V. Scenarios of Central European land fragmentation. Land Use Policy 2003, 20, 149-158. [CrossRef]

40. Ding, Y.M.; Ling, Y.; Yang, W.U. Path Choice of Rural Land Transfer in China. Asian Agric. Res. 2016, 8, 48-52.

41. Liu, W.B. Rural Land Transfer Model Innovation and Policy Suggestions in the Process of Urbanization. Econ. Rev. 2012, 3, 98-102. (In Chinese)

42. Li, H.S. Analysis of rural land transfer mode under the vision of accurate poverty alleviation. Forw. Position 2016, 6, 51-55. (In Chinese)

43. Ajzen, I. The theory of planned behavior. Organ. Behav. Hum. Decis. Process. 1991, 50, 179-211. [CrossRef]

44. Ajzen, I. From intentions to actions: A theory of planned behavior. In Action Control: From Cognition to Behavior; Kuhl, J., Beckmann, J., Eds.; Springer: Berlin/Heidelberg, Germany, 1985; pp. 11-39.

45. Ajzen, I.; Fishbein, M. Understanding Attitudes and Predicting Social Behavior; Prentice-Hall: Englewood Cliffs, NJ, USA, 1980.

46. Ajzen, I.; Fishbein, M. Belief, Attitude, Intention and Behavior: An Introduction to Theory and Research; Addison-Wesley: Reading, MA, USA, 1975.

47. Ajzen, I.; Fishbein, M. Attitudes and the Attitude-Behavior Relation: Reasoned and Automatic Processes. Eur. Rev. Soc. Psychol. 2000, 11, 1-33. [CrossRef]

48. Bagozzi, R.P. The Self-Regulation of Attitudes, Intentions, and Behavior. Soc. Psychol. Q. 1992, 55, $178-204$. [CrossRef]

49. Sniehotta, F.F.; Scholz, U.; Schwarzer, R. Bridging the intention-behaviour gap:planning, self-efficacy, and action control in the adoption and maintenance of physical exercise. Psychol. Health 2005, 20, 143-160. [CrossRef]

50. Richetin, J.; Perugini, M.; Conner, M.; Adjali, I.; Hurling, R.; Sengupta, A.; Greetham, D. To reduce and not to reduce resource consumption? That is two questions. J. Environ. Psychol. 2012, 32, 112-122. [CrossRef] 
51. Read, D.L.; Brown, R.F.; Thorsteinsson, E.B.; Morgan, M.; Price, I. The theory of planned behaviour as a model for predicting public opposition to wind farm developments. J. Environ. Psychol. 2013, 36, 70-76. [CrossRef]

52. Saeri, A.K.; Ogilvie, C.; La Macchia, S.T.; Smith, J.R.; Louis, W.R. Predicting Facebook users' online privacy protection: Risk, trust, norm focus theory, and the theory of planned behavior. J. Soc. Psychol. 2014, 154, 352-369. [CrossRef]

53. Colémont, A.; Broucke, S. Van Den Measuring determinants of occupational health related behavior in Flemish farmers: An application of the Theory of Planned Behavior. J. Saf. Res. 2008, 39, 55-64. [CrossRef]

54. Johnson, S.E.; Hall, A. The prediction of safe lifting behavior: An application of the theory of planned behavior. J. Saf. Res. 2005, 36, 63-73. [CrossRef]

55. Tonglet, M.; Phillips, P.S.; Read, A.D. Using the theory of planned behaviour to investigate the determinants of recycling behaviour: A case study from Brixworth, UK. Resour. Conserv. Recycl. 2004, 41, 191-214. [CrossRef]

56. Ramayah, T.; Lee, J.W.C.; Lim, S. Sustaining the environment through recycling: An empirical study. Manag. Environ. Qual. Int. J. 2013, 102, 141-147. [CrossRef]

57. Poškus, M.S. Predicting recycling behavior by including moral norms into the theory of planned behavior. Psychology 2015, 52, 22-32.

58. Xie, M.Z.; Yuan, M.X.; Guo, B. Study on the rural land transfer behavior based on theory of planned behavior. J. Xian Univ. Archit. Technol. 2013, 45, 300-304.

59. Promsopha, G. Land ownership as insurance and the market for land: A study in rural Vietnam. Land Econ. 2015, 91, 460-478. [CrossRef]

60. Li, S.W.; Wang, C.P.; Wei, M. Empirical analysis of peasant household land outflow behavior in major grain producing areas. Adv. Mater. Res. 2014, 962-965, 2229-2233.

61. Huang, J.K.; Gao, L.L.; Rozelle, S. The effect of off-farm employment on the decisions of households to rent out and rent in cultivated land in China. China Agric. Econ. Rev. 2012, 4, 5-17. [CrossRef]

62. Che, Y. Off-farm employments and land rental behavior: Evidence from rural China. China Agric. Econ. Rev. 2016, 8, 37-54. [CrossRef]

63. Deininger, K.; Jin, S. Securing property rights in transition: Lessons from implementation of China's rural land contracting law. J. Econ. Behav. Organ. 2007, 70, 22-38. [CrossRef]

64. Zhang, R.; Xiao, H.A. Influencing factors of householders' transferring out cultivated land under the background of urban and rural integration. Asian Agric. Res. 2011, 3, 120-123.

65. Feng, S. Land rental, off-farm employment and technical efficiency of farm households in Jiangxi Province, China. NJAS Wagening. J. Life Sci. 2008, 55, 363-378. [CrossRef]

66. Benin, S.; Ahmed, M.; Pender, J.; Ehui, S. Development of Land Rental Markets and Agricultural Productivity Growth: The Case of Northern Ethiopia. J. Afr. Econ. 2012, 14, 21-54. [CrossRef]

67. Deininger, K.; Jin, S. The potential of land rental markets in the process of economic development: Evidence from China. J. Dev. Econ. 2005, 78, 241-270. [CrossRef]

68. Matell, M.S.; Jacoby, J. Is there an optimal number of alternatives for likert scale items? study i: Reliability and validity. Educ. Psychol. Meas. 1971, 31, 657-674. [CrossRef]

69. Lubke, G.H.; Muthén, B.O. Applying multigroup confirmatory factor mrodels for continuous outcomes to likert scale data complicates meaningful group comparisons. Struct. Equ. Model. A Multidiscip. J. 2004, 11, 514-534. [CrossRef]

70. Yin, Z.Y.; Cheng, P.G.; Wang, Y.; Yuan, X.H. Willingness of farmland transfer from the perspective of the theory of planned behavior: Based on the data of 303 households in Jiangsu. J. Hunan Agric. Univ. (Soc. Sci.) 2012, 3, 1-7. (In Chinese)

71. Wei, F.; Yu, L.W. Analysis of factors affecting farmers' willingness to change houses-Based on survey of 24 natural villages in 8 townships of Baodi District, Tianjin. J. Agrotech. Econ. 2011, 12, 79-86. (In Chinese)

72. Wang, Y.H.; Liang, J.W.; Wang, Q.; Deng, X.T. Factors on electric vehicles purchase intention based on integrated model of TAM and PMT-Testsfrom 324 sample data. In Proceedings of the 19th China Management Science Academic Conference, Nanjing, China, 20 October 2017. (In Chinese). 
73. Ben, N.M.; Sharon, I.; Mahajna, M.; Mahajna, S. Factors affecting nursing students' intention to report medication errors: An application of the theory of planned behavior. Nurse Educ. Today 2017, 58, $38-42$.

74. Wei, F.; Yu, L.W. Analysis of factors affecting farmers' willingness to change houses based on logistic model*-Taking Baodi district of Tianjin as an example. Reform Econ. Syst. 2012, 2, 90-94. (In Chinese)

(C) 2019 by the authors. Licensee MDPI, Basel, Switzerland. This article is an open access article distributed under the terms and conditions of the Creative Commons Attribution (CC BY) license (http://creativecommons.org/licenses/by/4.0/). 